\title{
Wyznaczanie całkowitej zawartości węgla organicznego TOC w skałach łupkowych z wykorzystaniem profilowań geofizyki otworowej na przykładzie danych z basenu bałtyckiego
}

\begin{abstract}
Wyznaczenie całkowitej zawartości węgla organicznego (TOC) jest ważnym elementem procesu oceny skał łupkowych jako niekonwencjonalnych złóż węglowodorów. TOC to podstawowy wskaźnik perspektywiczności skały. Jego pomiar w laboratorium przy zastosowaniu pirolizy Rock-Eval dostarcza jedynie informacji punktowej. Zwiększenie liczby próbek wiąże się ze znacznym wzrostem kosztów prowadzonych badań. W pracy dopasowano wybrane metody statystyczne do obliczania TOC w utworach syluru i ordowiku w basenie bałtyckim, wykorzystując profilowania geofizyki otworowej. Zastosowana metodyka pozwoliła na uzyskanie wartości tego parametru w sposób ciągły bez wzrostu kosztów prowadzonych badań. Wykorzystano aplikację TOC systemu GeoWin, będącą narzędziem do automatycznego obliczania zawartości węgla organicznego. Aplikacja ta stosuje metodę Passeya, a także znane z literatury wzory empiryczne, w których współczynniki zostały wyliczone na podstawie wielowymiarowych analiz statystycznych. Wykorzystano profilowania geofizyki otworowej, takie jak: spektrometryczne profilowanie gamma $(\mathrm{K}, \mathrm{U}, \mathrm{TH})$, profilowanie gęstości objętościowej (RHOB), profilowanie porowatości neutronowej (NPHI) oraz profilowanie oporności elektrycznej w strefie niezmienionej (LLD). Analizie poddano także wyniki badań laboratoryjnych próbek z rdzeni wiertniczych z pięciu otworów leżących w obrębie syneklizy perybałtyckiej i wyniesienia Łeby, będących strukturalną częścią kratonu wschodnioeuropejskiego. Z punktu widzenia poszukiwania gazu w badanych profilach geologicznych interesujące są dwie formacje: sylurska (landower) formacja iłowców z Pasłęka z ogniwem z Jantaru w spągowej części oraz ordowicka (karadok/lanwirn) formacja iłowców z Sasina. W związku z położeniem otworów w obrębie różnych jednostek geologicznych akumulacja węglowodorów przebiegała $\mathrm{w}$ odmiennych warunkach, co odzwierciedla się w wyznaczonych na podstawie profilowań geofizyki otworowej parametrach. Obliczenia statystyczne wykonano dla badanych formacji w poszczególnych otworach. Wyznaczono również ogólne współczynniki równań dla analizowanego obszaru, pozwalające na szybką estymację całkowitej zawartości węgla organicznego.
\end{abstract}

Słowa kluczowe: całkowita zawartość węgla organicznego - TOC, profilowania geofizyki otworowej, metoda Passeya, metody empiryczne, lupki ordowickie i sylurskie.

\section{Use of empirical methods based on well logging to calculate the total organic carbon content in Baltic Basin's shale gas reservoir}

Calculations of total organic carbon (TOC) is one of the most important parts of interpretation in shale gas reservoirs and it is one of main indicators of perspective zones. Laboratory methods to measure total organic carbon such as Rock-Eval pyrolysis, give only the point data results. Increase in the number of samples causes a significant increase in the cost of surveys. This article fits the selected methods of total organic carbon determination based on well logging data, which allows to calculate TOC in all measured intervals without an increase in costs. In order to estimate TOC, different mathematical equations were used, such as that implemented in TOC application in the GeoWin system, which is a tool for automatic total organic carbon estimation based on the Passey method and other empirical equations. All factors were calculated using multidimensional statistical analysis made on well logs such as spectral gamma ray (K, U, TH), bulk density (RHOB), neutron porosity (NPHI), electric resistivity (LLD). Wells are placed in Poland, on the Łeba Elevation and the Peri-Baltic Syneclise, which is located on the onshore part of the Baltic Basin. The analysis was carried out on well logs and core data from five wells located within 
the Peri-Baltic Syneclise and the Łeba Elevation being a structural part of the East European Platform. The most perspective gas-bearing sediments are thought to be Silurian member of bituminous shales from Jantar and Ordovician level of the Sasino claystone formation, rich in organic matter. Due to the location of wells in different geological units, accumulation of hydrocarbons took place in different conditions, which is reflected in the calculated parameters. The Authors, using the calculations, have tried to fit the general coefficient of equations for the whole analyzed area, allowing for fast estimation of TOC. Key words: total organic carbon - TOC, well logs, Passey method, empirical methods, Ordovician and Silurian shales.

\section{Wstęp}

Całkowita zawartość węgla organicznego (ang. total organic carbon - TOC) wyznaczana w skałach łupkowych jest podstawowym parametrem charakteryzującym występowanie stref potencjalnie perspektywicznych do eksploatacji niekonwencjonalnych złóż węglowodorów. TOC może być pomierzone zarówno za pomocą badań laboratoryjnych na próbkach wyciętych z rdzeni wiertniczych, jak i na podstawie pomiarów geofizyki otworowej. Najczęściej wykorzystywaną metodą laboratoryjną wyznaczania TOC jest piroliza Rock-Eval, natomiast wśród metod opartych na pomiarach otworowych dominuje metoda Passeya [6, 9]. Warto jednak wymienić także inne metody wykorzystujące empiryczne relacje pomiędzy parametrami dostarczanymi przez profilowania geofizyki otworowej a zawartością węgla organicznego.

Korzystając z aplikacji TOC systemu GeoWin oraz dostępnych w literaturze wzorów empirycznych, autorzy przeprowadzili serię wielokrotnych obliczeń TOC na danych z otworów leżących w obrębie basenu bałtyckiego. Dobór współczynników w równaniach empirycznych wykonano przy użyciu wielowymiarowych analiz statystycznych.

\section{Zarys budowy geologicznej obszaru badań}

Analizy przeprowadzono na danych pochodzących z wyniesienia Łeby (otwory C i D) oraz z obszaru syneklizy perybałtyckiej (otwory A, B, E), w obrębie lądowej części basenu bałtyckiego (rysunek 1). Synekliza jest rozległą, otwartą w kierunku południowo-zachodnim monokliną będącą strukturalną częścią kratonu wschodnioeuropejskiego [5]. Zbudowana jest z osadów paleozoiku, permu, triasu, jury, kredy, trzeciorzędu oraz czwartorzędu o miąższości od kilkuset metrów w części wschodniej do $5 \mathrm{~km}$ w części zachodniej. Wyniesienie Łeby, leżące w południowo-zachodniej części syneklizy, stanowi element tektoniczny o charakterze zrębowym. $Z$ punktu widzenia poszukiwania gazu najbardziej perspektywiczne utwory stanowią bogate w materię organiczną sylurskie i ordowickie łupki, które rozciągają się wzdłuż zachodniej krawędzi platformy wschodnioeuropejskiej, między innymi w basenie bałtyckim [7]. Można w nich wydzielić dwie jednostki: spągową część formacji iłowców z Pasłęka - sylurskie ogniwo czarnych iłowców bitumicznych z Jantaru oraz ordowicką formację iłowców z Sasina. Badania laboratoryjne wykazały, że maksymalna zawartość materii organicznej w ogniwie z Jantaru dla badanych otworów waha się w przedziale $4,91 \div 7,3 \%$ wag., natomiast $\mathrm{w}$ formacji $\mathrm{z}$ Sasina $0,99 \div 5,95 \% \mathrm{wag}$. [1].

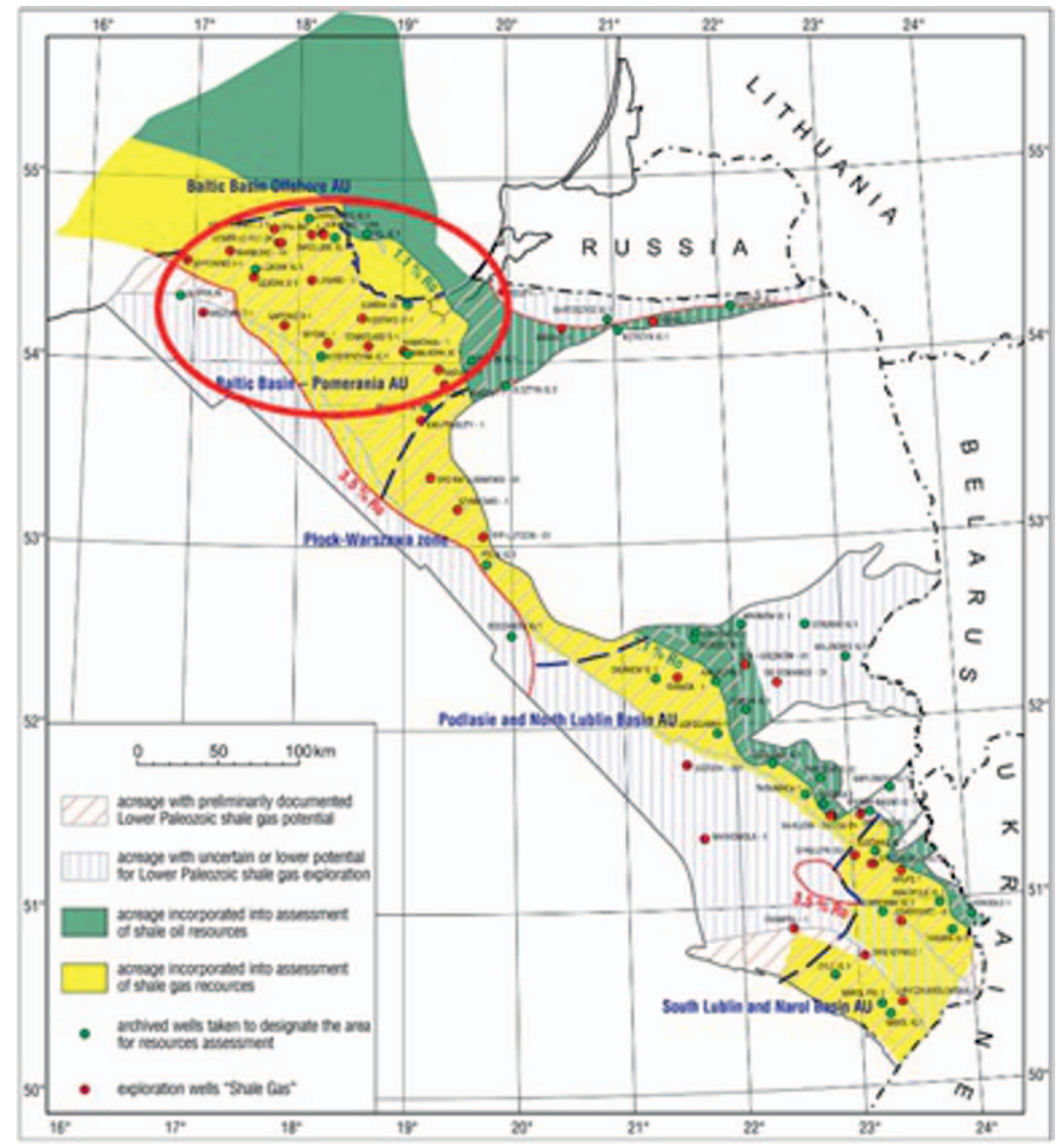

Rys. 1. Obszary generowania ropy i gazu w utworach syluru i ordowiku ([2]; zmodyfikowane) 


\section{Wyznaczanie TOC metodą Passeya}

Metoda estymacji całkowitej zawartości węgla organicznego metodą Passeya [6] opiera się na odpowiednim graficznym zestawieniu wyników profilowania akustycznego (czasu interwałowego DT wyrażonego w mikrosekundach na stopę) oraz profilowania oporności w strefie niezmienionej (oporności RT z pomiaru sondami LLD lub ILD).

Zamiennie z profilowaniem akustycznym wykorzystywane są profilowania gęstościowe lub neutronowe w postaci odpowiednio: gęstości objętościowej (RHOB) lub porowatości neutronowej (NPHI). Zestawienia graficzne wyników profilowań geofizyki otworowej muszą spełnić następujące warunki: krzywe powinny się pokrywać w skałach zailonych, niebędących skałami macierzystymi, przy odpowiednim zestawieniu skali, tj. dekada na skali logarytmicznej oporności pozornej odpowiada $50 \mu \mathrm{s} / \mathrm{st}$. czasu interwałowego przy odwróconej skali DT lub $0,4 \mathrm{~g} / \mathrm{cm}^{3}$ gęstości objętościowej (skala nieodwrócona), lub 0,25 porowatości neutronowej (skala odwrócona). Wyznaczanie TOC na podstawie anomalii na wymienionych krzywych jest możliwe, ponieważ materia organiczna występująca w skale powoduje wzrost oporności elektrycznej, wzrost czasu interwałowego i porowatości neutronowej oraz spadek gęstości objętościowej. W związku z tym odpowiednie zestawienie krzywych skutkuje ich rozejściem w interwałach, w których występuje materia organiczna. Parametr dlogR, określający rozejście krzywych, jest podstawową wielkością w metodzie Passeya. Do jego wyznaczenia należy określić wartości RT, DT, RHOB i NPHI w miejscu pokrycia się profilowań. Metoda Passeya została zaimplementowana w aplikacji TOC w systemie GeoWin [4], dzięki czemu obliczenia są szybkie. W rejonie basenu bałtyckiego obliczenia z wykorzystaniem metody Passeya przeprowadzono dla pięciu otworów, a następnie wyniki porównano z oznaczeniami laboratoryjnymi na próbkach z rdzeni wiertniczych (tablica 1, rysunek 2).

W otworach A i E obserwuje się niskie współczynniki dopasowania między TOC wyznaczonym metodą Passeya a wynikami badań laboratoryjnych. Współczynniki wyraźnie odbiegają od wartości w pozostałych otworach. Na podstawie badań geo- chemicznych próbek skał łupkowych w tych otworach można stwierdzić, że materia organiczna jest bardziej dojrzała, a indeks wodorowy niższy. Otwory te znajdują się w najbardziej na południe wysuniętej części obszaru badań, a warstwy najbogatsze w materię organiczną (sweet spots) są położone najgłębiej.
Tablica 1. Wartości współczynników dopasowania $R^{2}$ pomiędzy TOC wyznaczonym metodą Passeya a wynikami badań laboratoryjnych na rdzeniach

\section{Współczynniki dopasowania $R^{2}$ dla całego otworu}

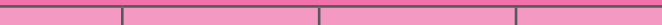

\begin{tabular}{l|l|c|c} 
& Otwór B & Otwór C & Otwór D \\
$n=223$ & $n=215$ & $n=508$ & $n=249$
\end{tabular}

Otwór E $n=229$

\begin{tabular}{c|c|c|c|c} 
& $n=215$ & $n=508$ & $n=249$ & $n=229$ \\
\hline 0,20 & 0,46 & 0,64 & 0,57 & 0,20
\end{tabular}

\begin{tabular}{l|l|l}
0,10 & 0,41 & 0,55 \\
\hline
\end{tabular}

\begin{tabular}{l|l|l}
0,16 & 0,40 & 0,63
\end{tabular}

\begin{tabular}{l|l}
0,55 & 0,52 \\
\hline 0,63 & 0,57
\end{tabular}

0,19

0,08

czynniki dopasowania $R^{2}$ dla formacji z Pasłęka i Sasina

\begin{tabular}{|c|c|c|c|c|}
\hline$=93$ & $n=80$ & $n=80$ & $n=135$ & $n=100$ \\
\hline 0,02 & 0,53 & 0,68 & 0,61 & 0,44 \\
\hline 0,06 & 0,52 & 0,31 & 0,58 & 0,13 \\
\hline 0,07 & 0,55 & 0,66 & 0,61 & 0,56 \\
\hline
\end{tabular}

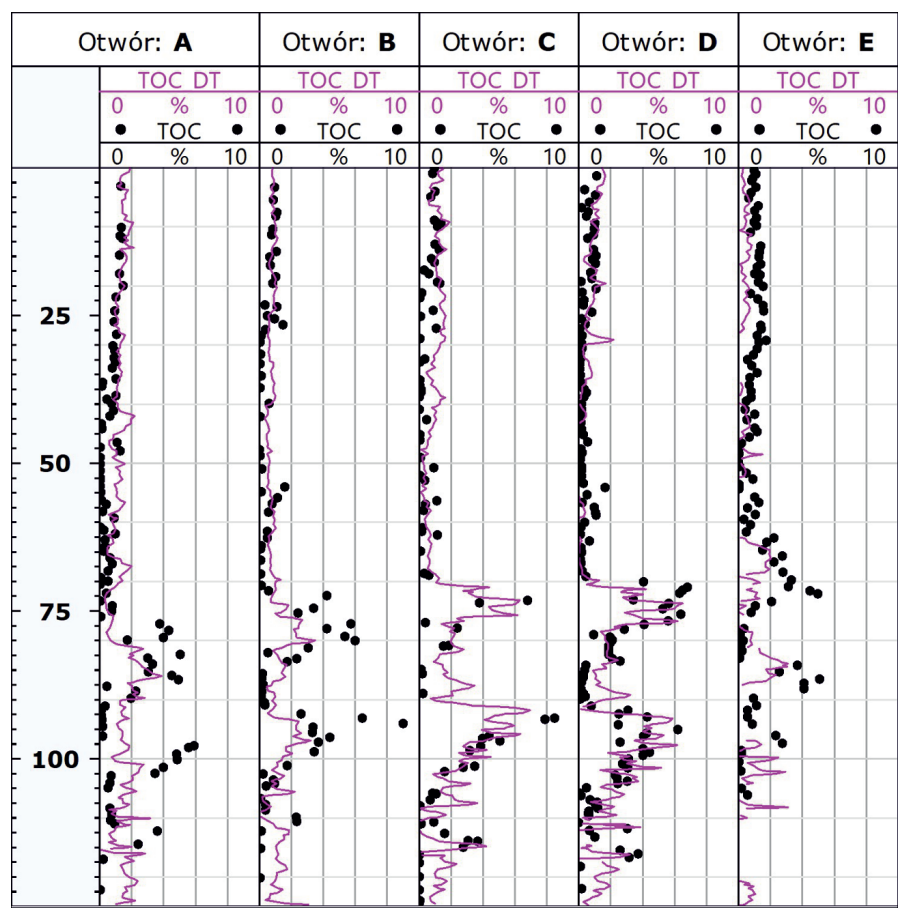

Rys. 2. Zestawienie wartości TOC [\% wag.] wyznaczonych na podstawie metody Passeya (kombinacja DT-LLD) z wynikami pomiarów laboratoryjnych na próbkach z rdzeni wiertniczych

\section{Empiryczne metody wyznaczania TOC}

Wyznaczanie zawartości węgla organicznego na podstawie profilowań geofizyki otworowej możliwe jest także dzięki wykorzystaniu empirycznych zależności. Wzrost zawartości TOC powoduje zmianę własności fizycznych ośrodka, co skutkuje zmianą wskazań sond pomiarowych. W związku z tym sprawdzono korelację pomiędzy pomierzoną w badaniach laborato- 
ryjnych zawartością węgla organicznego a wybranymi profilowaniami i ich kombinacjami (rysunek 3) [8] w celu znalezienia najbardziej efektywnej metody wyznaczania TOC. Współczynniki równań dla poszczególnych otworów zostały obliczone na podstawie wielowymiarowej analizy statystycznej.

W artykule przedstawione zostały trzy metody, dla których dopasowanie jest największe, zarówno w przypadku całego otworu, jak i interwałów perspektywicznych.

Pierwszą jest metoda oparta na spektrometrycznym profilowaniu gamma. Zawartość uranu w skale powiązana jest w głównej mierze z występowaniem materii organicznej. Stosunek zawartości uranu do toru świadczy o obecności materii organicznej w łupkach [3]. Udział TOC w skale wyrażony jest formułą (1) oznaczoną jako metoda I:

$$
\mathrm{TOC}=a(\mathrm{U}-\mathrm{U} / \mathrm{K})+b
$$
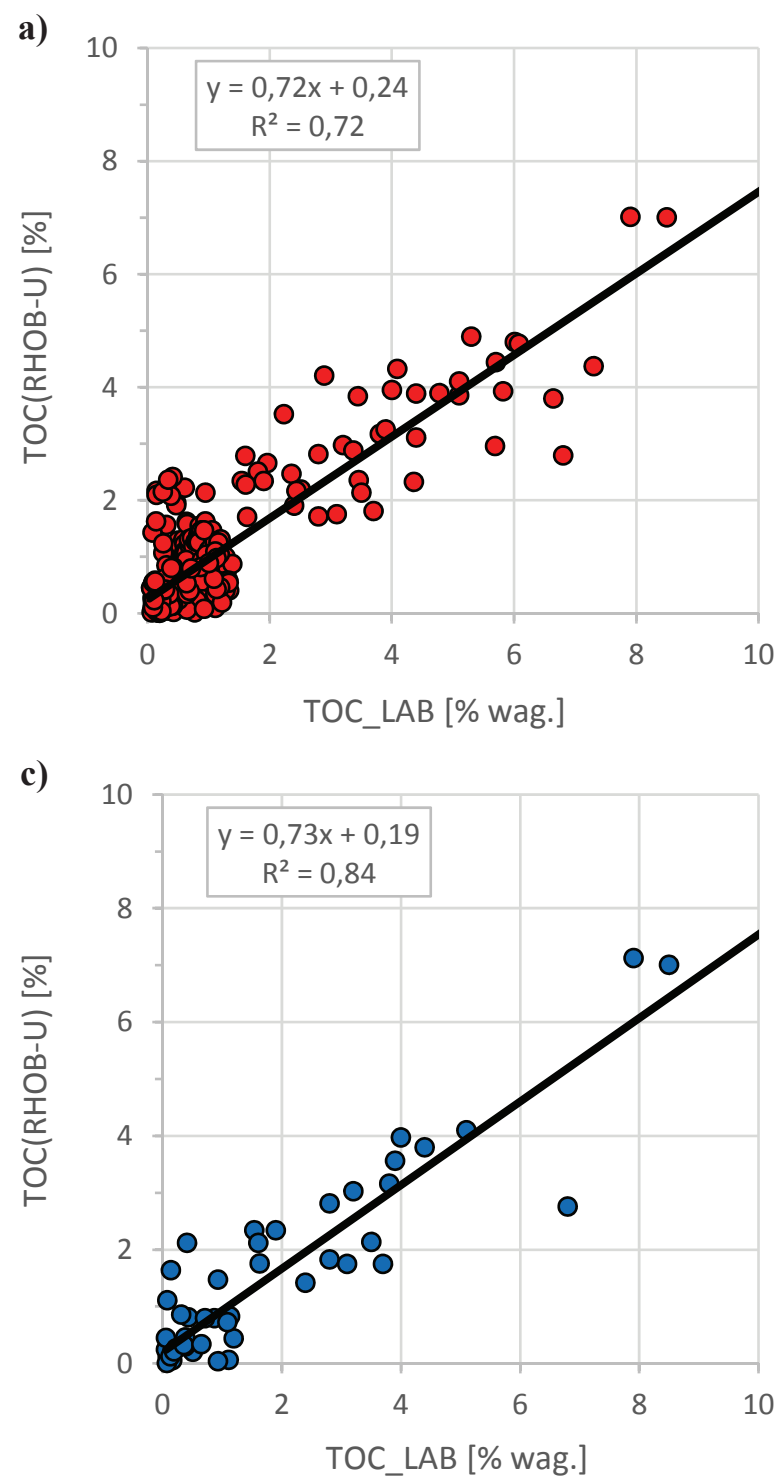

gdzie:

TOC - całkowita zawartość węgla organicznego w skale

[\% wag.],

$\mathrm{U}$ - zawartość uranu [ppm],

$\mathrm{K}$ - zawartość potasu [\%],

$a$ i $b$-empirycznie wyznaczone współczynniki.

Kolejne dwie metody (metoda II i III) opierają się na równaniu (2):

$$
\mathrm{TOC}=a_{1} \cdot X_{1}+a_{2} \cdot X_{2}+\ldots+a_{\mathrm{n}} \cdot X_{\mathrm{n}}+b
$$

gdzie:

$a_{1}, \ldots, a_{n}, b$-empirycznie wyznaczone współczynniki,

$X_{1}, \ldots, X_{\mathrm{n}}$ - parametry mierzone przez wybrane profilowania geofizyki otworowej,

$n$ - liczba wykorzystywanych profilowań.
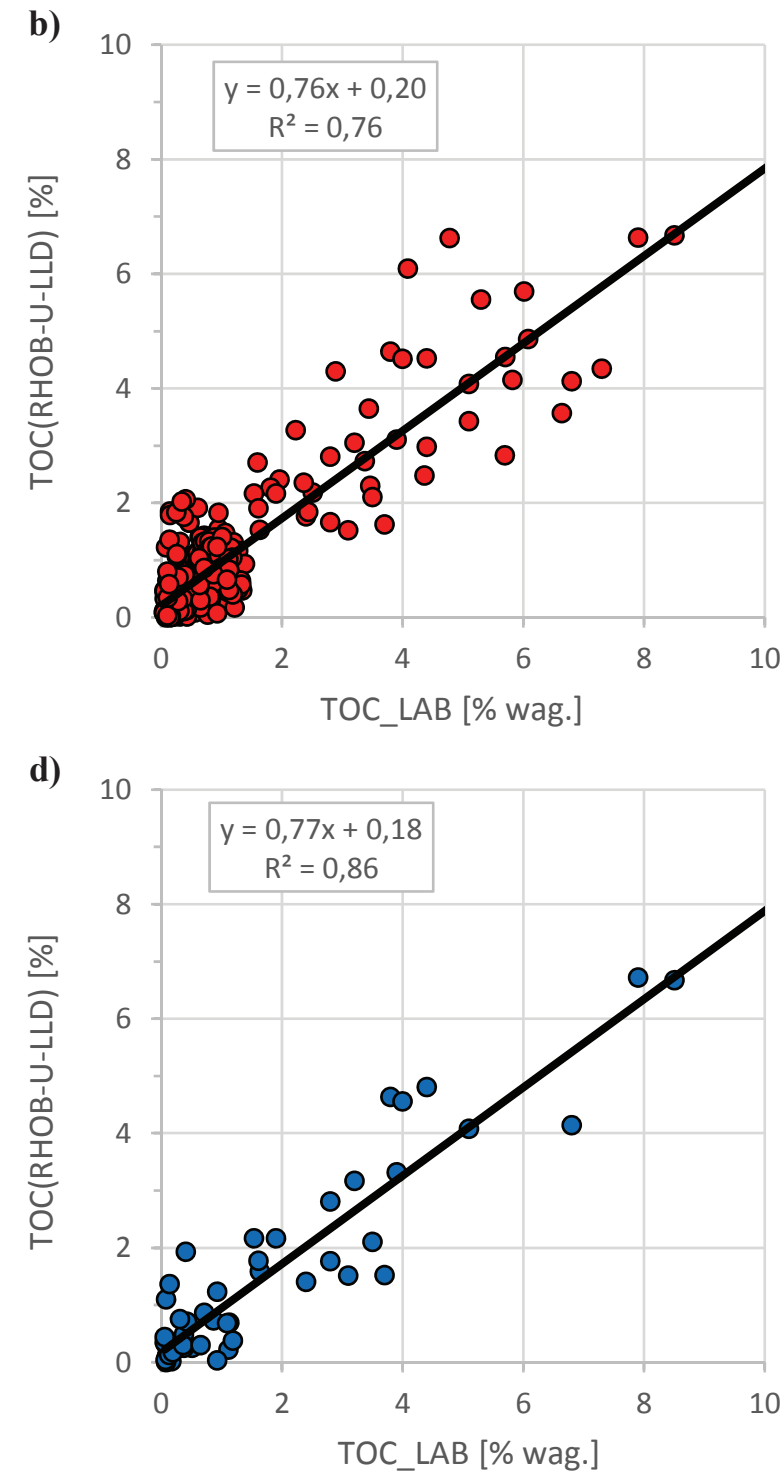

Rys. 3. Wykresy zależności dla otworu C pomiędzy zawartością TOC zmierzoną w laboratorium a TOC wyliczonym za pomocą metod empirycznych: a) metoda RHOB-U w całym otworze; b) metoda RHOB-U-LLD w całym otworze; c) metoda RHOB-U w formacjach z Pasłęka i Sasina; d) metoda RHOB-U-LLD w formacjach z Pasłęka i Sasina 
Do analizy wybrano następujące wielkości: RHOB (gęstość objętościowa z profilowania gamma-gamma), U (zawartość uranu ze spektrometrycznego profilowania gamma) oraz LLD (oporność elektryczna zarejestrowana laterologiem dalekiego zasięgu). Użyte parametry: RHOB, U, LLD pokazały najlepsze korelacje z wynikami badań laboratoryjnych na próbkach z rdzeni wiertniczych. Profilowania dostarczające tych parametrów należą do pomiarów powszechnie wykonywanych w otworach wiertniczych.
Wartości współczynników dopasowania $R^{2}$ pomiędzy TOC wyestymowanym na podstawie metod empirycznych dla pojedynczych otworów a wynikami badań laboratoryjnych na próbkach z rdzeni wiertniczych zestawiono w tablicy 2. Wyniki wyliczonego TOC przedstawiono na ścieżkach wraz z nałożonymi wynikami badań Rock-Eval (rysunek 4).

Najlepsze dopasowanie TOC wyestymowanego na podstawie metod empirycznych I, II, III z wynikami badań laboratoryjnych dla wszystkich otworów wiertniczych, dla

Tablica 2. Wartości współczynników dopasowania $R^{2}$ pomiędzy TOC wyestymowanym na podstawie metod empirycznych I, II, III zastosowanych dla pojedynczych otworów a wynikami badań laboratoryjnych; $n$ - liczba próbek laboratoryjnych wykorzystanych w analizie

\begin{tabular}{|c|c|c|c|c|c|c|}
\hline \multicolumn{7}{|c|}{ Współczynniki dopasowania $R^{2}$ dla całego otworu } \\
\hline Nr metody & Metoda & $\begin{array}{c}\text { Otwór A } \\
n=223\end{array}$ & $\begin{array}{c}\text { Otwór B } \\
n=215\end{array}$ & $\begin{array}{c}\text { Otwór C } \\
n=508\end{array}$ & $\begin{array}{c}\text { Otwór D } \\
n=249\end{array}$ & $\begin{array}{c}\text { Otwór E } \\
n=229\end{array}$ \\
\hline I & U-U/K & 0,07 & 0,60 & 0,56 & 0,58 & 0,24 \\
\hline II & RHOB-U & 0,10 & 0,65 & 0,72 & 0,68 & 0,16 \\
\hline III & RHOB-U-LLD & 0,19 & 0,67 & 0,76 & 0,71 & 0,39 \\
\hline \multicolumn{7}{|c|}{ Współczynniki dopasowania $R^{2}$ dla formacji z Pasłęka i Sasina } \\
\hline Nr metody & Metoda & $n=93$ & $n=80$ & $n=80$ & $n=135$ & $n=100$ \\
\hline I & U-U/K & 0,13 & 0,62 & 0,71 & 0,77 & 0,54 \\
\hline II & RHOB-U & 0,15 & 0,65 & 0,84 & 0,81 & 0,29 \\
\hline III & RHOB-U-LLD & 0,23 & 0,66 & 0,86 & 0,80 & 0,34 \\
\hline
\end{tabular}

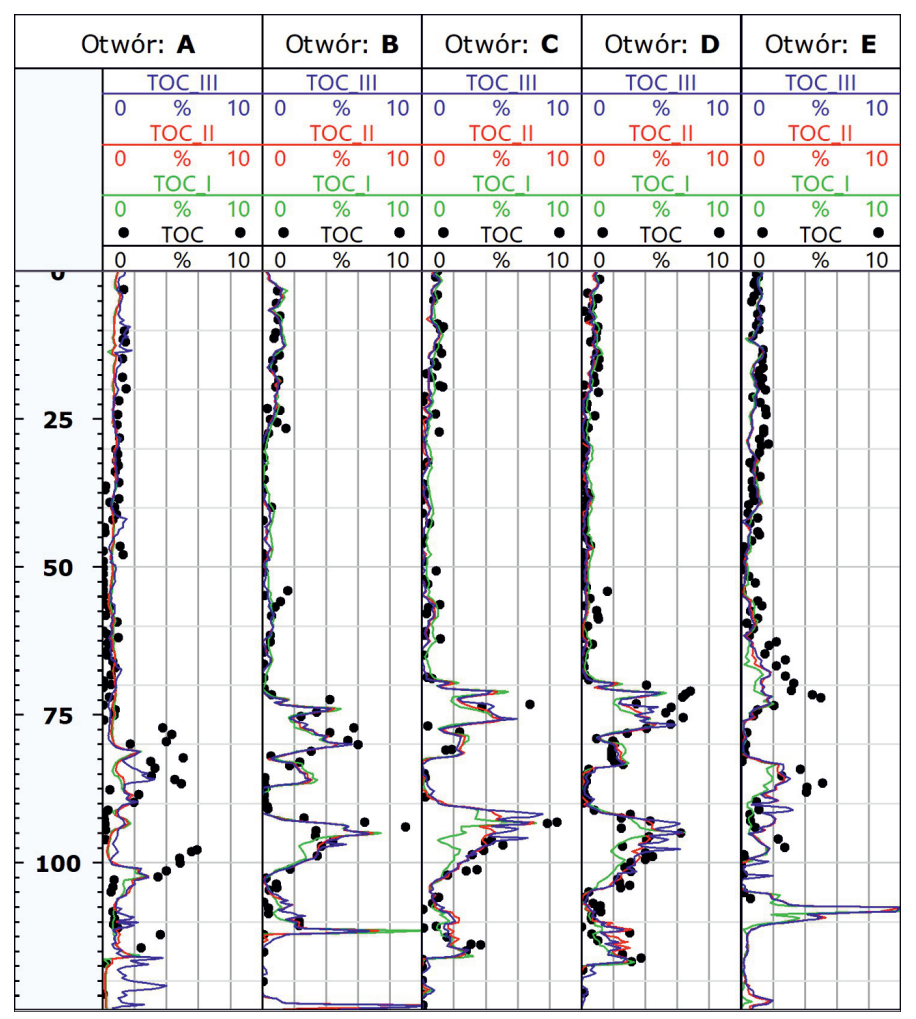

Rys. 4. Zestawienie wyestymowanych wartości TOC [\% wag.] na podstawie wybranych metod empirycznych I, II, III zastosowanych dla pojedynczych otworów z wynikami badań laboratoryjnych

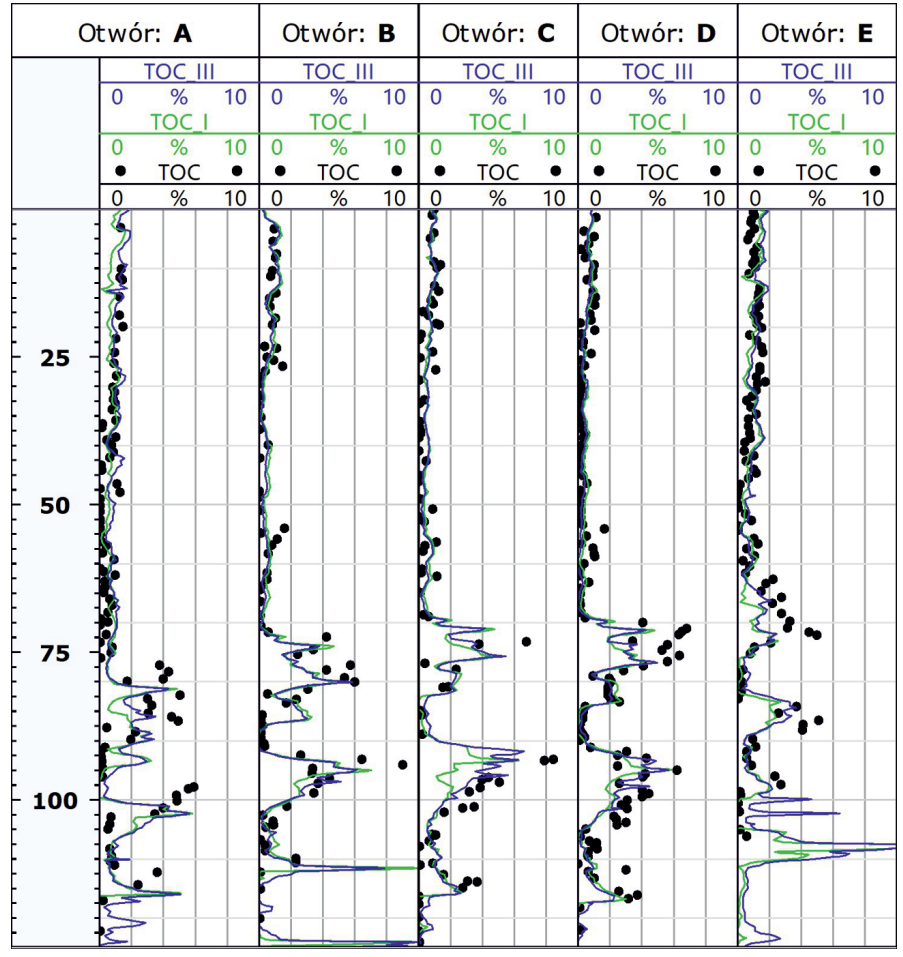

Rys. 5. Zestawienie wyestymowanych wartości TOC [\% wag.] na podstawie wybranych metod empirycznych z wykorzystanymi ogólnymi współczynnikami dopasowania 
całego interwału uzyskano w przypadku metody III, czyli po zastosowaniu kombinacji profilowań: RHOB, U i LLD. Natomiast współczynnik dopasowania w utworach formacji z Pasłęka i Sasina osiągnął najwyższe wartości dla metody III w otworach: A, B, C, dla metody II w otworze D i metody I w otworze E.

Na podstawie powyższych obserwacji postanowiono znaleźć współczynniki odpowiednie dla całego obszaru basenu bałtyckiego. Obliczenia przeprowadzono dla metod I i III, gdyż dla nich otrzymano najlepsze wyniki - zarówno w przypadku całego otworu, jak i interwału perspektywicznego. Metoda III jest rozwinięciem metody II. W analizie wykorzystano $n=1425$ próbek. W wyniku regresji prostej oraz regresji wielorakiej uzyskano następujące równania (3) i (4):

$$
\mathrm{TOC}=0,467(\mathrm{U}-\mathrm{U} / \mathrm{K})-0,646
$$

$$
\mathrm{TOC}=0,195 \cdot \mathrm{RHOB}+0,322 \cdot \mathrm{U}+0,008 \cdot \mathrm{LLD}-1,361
$$

Otrzymane miary dopasowania $R^{2}$ dla metod odnoszących się do całego obszaru basenu bałtyckiego nie są satysfakcjonujące i wynoszą odpowiednio: 0,45 oraz 0,52 . Podobnie jak w tablicy 1 - obecnie też obserwuje się niskie wartości współczynników dopasowania w otworach A i E. Wyniki obliczeń w postaci krzywych profilowań i punktowych danych laboratoryjnych zostały przedstawione na rysunku 5.

\section{Wnioski}

1. Przeprowadzone analizy jednoznacznie wykazały zasadność stosowania empirycznych metod estymowania zawartości TOC wykorzystujących profilowania geofizyki otworowej. Pomimo znacznego zakresu zmienności współczynnika dopasowania $R^{2}$ metody te posiadają szereg zalet. Uzyskane współczynniki $R^{2}$ były podobne lub większe w stosunku do metody Passeya, przy jednoczesnym niewielkim czasie obliczeń i wyeliminowaniu subiektywnego czynnika występującego w metodzie Passeya.

2. Pozytywnym aspektem stosowanych metod jest zwiększanie dopasowania między wynikami obliczeń na podstawie geofizyki otworowej i badań laboratoryjnych na próbkach z rdzeni wiertniczych w interwałach o podwyższonej zawartości TOC.
3. Przedstawione równania dzięki swojej prostocie mogą być użyteczne przy wstępnych analizach przed wykorzystaniem bardziej zaawansowanych procedur obliczeniowych, na przykład z zastosowaniem sztucznych sieci neuronowych.

4. Próba empirycznego określenia współczynników równań dla basenu bałtyckiego nie zakończyła się w pełni satysfakcjonującym wynikiem. Powodem takiej sytuacji może być znaczna zmienność formacji skalnych wynikająca ze zróżnicowania składu mineralnego, odmiennego wykształcenia przestrzeni porowej oraz zmiany zawartości TOC (obserwowany jest spadek w kierunku południowym) pomiędzy analizowanymi otworami oraz zróżnicowane głębokości występowania sweet spotów. W związku z tym bardziej efektywne jest stosowanie omówionych metod dla pojedynczych otworów.

\section{Podziękowania}

Praca została wykonana dzięki uprzejmości firmy PGNiG SA, która udostępniła dane geologiczne, wyniki badań laboratoryjnych na próbkach z rdzeni wiertniczych i profilowania geofizyki otworowej.

Prosimy cytować jako: Nafta-Gaz 2018, nr 11, s. 789-795, DOI: 10.18668/NG.2018.11.02

Artykuł nadesłano do Redakcji 4.10.2018 r. Zatwierdzono do druku 28.11.2018 r.

Artykuł został opracowany na podstawie referatu wygłoszonego na Międzynarodowej Konferencji Naukowo-Technicznej GEOPETROL 2018 pt.: Rozwój technik poszukiwania i eksploatacji złóż węglowodorów. Zakopane-Kościelisko, 17-20.09.2018 r.

\section{Literatura}

[1] Jarzyna J., Wawrzyniak-Guz K. (red.): Adaptacja do warunków polskich metodologii wyznaczania sweet spotów na podstawie korelacji pomiarów geofizycznych z rdzeniami wiertniczymi. Wydawnictwa AGH, Kraków 2017.

[2] Kiersnowski H., Dyrka I.: Ordovician-Silurian shale gas resources potential in Poland: Evaluation of Gas Resources Assessment Reports published to date and expected improvements for 2014 forthcoming Assessment. Przegląd Geologiczny 2013, vol. 61, nr 11, s. 639-656.

[3] Klaja J., Dudek L.: Geological interpretation of spectral gamma ray (SGR) logging in selected boreholes. Nafta-Gaz 2016, $\mathrm{nr} 1$, s. 3-14, DOI: DOI: 10.18668/NG2016.01.01.

[4] Krakowska P., Wawrzyniak-Guz K., Puskarczyk E., Karczewski J., Jarzyna J.: Aplikacja TOC w systemie GeoWin do obliczania całkowitej zawartości węgla organicznego na podstawie profilowań geofizyki otworowej. Prace Naukowe Instytutu Nafty i Gazu - PIB 2016, nr 209, wydanie konferencyjne, s. 575-579.

[5] Modliński Z., Szymański B., Teller L.: The Silurian lithostratigraphy of the Polish part of the Peri-Baltic depression (N Poland). Przeglad Geologiczny 2003, vol. 54, nr 9, s. 787-796. 
[6] Passey Q.R., Creaney S., Kulla J.B., Moretti F.J., Stroud J.D.: A practical model for organic richness from porosity and resistivity logs. AAPG Bulletin 1990, vol. 74, nr 12, s. 1777-1794.

[7] Podhalańska T., Waksmundzka M.I., Becker A., Roszkowska-Remin J., Dyrka I., Feldman-Olszewska A., Głuszyński A., Grotek I., Janas M., Karcz P., Nowak G., Pacześna J., Roman M., Sikorska-Jaworowska M., Kuberska M., Kozłowska A., Sobień K.: Strefy perspektywiczne występowania niekonwencjonalnych złóż węglowodorów w kambryjskich, ordowickich, sylurskich i karbońskich kompleksach skalnych Polski: integra- cja wyników badań. Przegląd Geologiczny 2016, vol. 64, nr 12, s. $1008-1021$.

[8] Renchun H., Yan W., Sijie C., Shuai L., Li C.: Selection of logging-based TOC calculation methods for shale reservoirs: A case study of the Jiaoshiba shale gas field in the Sichuan Basin. Natural Gas Industry B 2015, vol. 2, nr 2-3, s. 155-161.

[9] Schmoker J.: Determination of organic content of appalachian devonian shales from formation density log. AAPG Bulletin 1979, vol. 63, nr 9, s. 1504-1537.

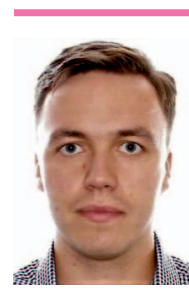

Mgr inż. Sebastian WASZKIEWICZ

Doktorant na Wydziale Geologii, Geofizyki i Ochrony

Środowiska, Katedra Geofizyki

Akademia Górniczo-Hutnicza im. St. Staszica

al. Mickiewicza 30

30-059 Kraków

E-mail:waszkiewicz@agh.edu.pl

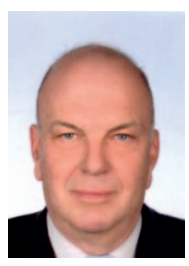

Dr inż. Jerzy KARCZEWSKI

Adiunkt na Wydziale Geologii, Geofizyki i Ochrony

Środowiska, Katedra Geofizyki

Akademia Górniczo-Hutnicza im. St. Staszica

al. Mickiewicza 30

30-059 Kraków

E-mail:karcz@agh.edu.pl

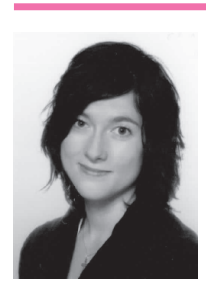

Dr inż. Paulina KRAKOWSKA

Adiunkt na Wydziale Geologii, Geofizyki

i Ochrony Środowiska

Akademia Górniczo-Hutnicza im. St. Staszica

w Krakowie

al. Mickiewicza 30, 30-059 Kraków

E-mail.krakow@agh.edu.pl

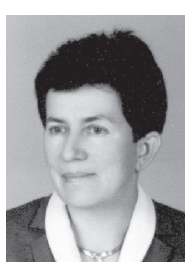

Prof. dr hab. inż. Jadwiga JARZYNA

Profesor zwyczajny

Wydział Geologii, Geofizyki i Ochrony Środowiska

Akademia Górniczo-Hutnicza im. St. Staszica

w Krakowie

al. Mickiewicza 30, 30-059 Kraków

E-mail:jarzyna@agh.edu.pl

\section{OFERTA}

\section{ZAKŁAD GEOFIZYKI WIERTNICZEJ}

Zakres działania:

- badania tomograficzne skał:

» trójwymiarowa wizualizacja i analiza wewnętrznej struktury przestrzeni porowej skał metodą mikrotomografii rentgenowskiej (micro-CT)

" tomografia metrowych odcinków skał, profilowanie zmian parametrów petrofizycznych rdzenia (porowatość, gęstość objętościowa);

- badania metodą jądrowego rezonansu magnetycznego:

" określanie rozkładu nasycenia wodą przestrzeni porowej próbek,

" generacja map T1-T2, szacowanie nasycenia woda/węglowodorami,

" identyfikacja obecności substancji organicznej TOC;

- oznaczanie jakościowego i ilościowego składu mineralnego skał oraz wydzielonej frakcji ilastej na podstawie analizy rentgenowskiej:

- $\quad$ wyznaczanie zawartości naturalnych pierwiastków promieniotwórczych: uranu, toru i potasu w skałach, płuczkach wiertniczych i materiałach budowlanych;

- $\quad$ ocena elektrycznych parametrów skał (wskaźnika struktury porowej i zwilżalności);

- $\quad$ określanie zależności elektrycznej oporności właściwej płuczek wiertniczych od temperatury;

- $\quad$ ocena prędkości propagacji fal ultradźwiękowych w skałach, kamieniach cementowych i płuczkach wiertniczych

- badanie przewodności cieplnej skał;

- $\quad$ wyznaczane współczynnika przepuszczalności;

- badanie gęstości, gęstości właściwej i porowatości;

- interpretacja profilowań geofizycznych w zakresie oceny stanu zacementowania rur okładzinowych w otworach

- badania serwisowe:

" analiza chemiczna skał metodą fluorescencji rentgenowskiej;

» spektrometryczne pomiary gamma na rdzeniu wiertniczym: ${ }^{40} \mathrm{~K},{ }^{238} \mathrm{U},{ }^{232} \mathrm{Th}$, total gamma przy wykorzystaniu mobilnego urządzenia "Gamma Logger".

Kierownik: dr inż. Marek Dohnalik

Adres: ul. Bagrowa 1, 30-733 Kraków

Telefon: 126506770

Faks: 1261774 70, 126531665

E-mail: marek.dohnalik@inig.pl

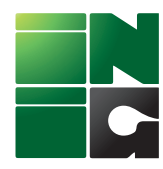

